Nadwa : Jurnal Pendidikan Islam

Vol. 12, Nomor 2 Tahun 2018

Accredited by Ristekdikti based on Decree No. 51/E/KPT/2017

\title{
College Students' Perception about the Implementation of Democratic and Humanist Learning Model in State Islamic Institute (IAIN) Sultan Amai Gorontalo
}

\author{
Siti Asiah T. \\ IAIN Sultan Amai Gorontalo \\ asiahpido@iaingorontalo.ac.id \\ Herson Anwar \\ IAIN Sultan Amai Gorontalo \\ herson.anwar@iaingorontalo.ac.id
}

\begin{abstract}
This research aims to analyse the perception of students of Islamic Education Management Study Program at Faculty of Teacher Training and Education, Islamic State University (IAIN) Sultan Amai Gorontalo about the implementation of democratic and humanist learning model. The sample used in the research was 98 respondents. The data analysis technique used was descriptive statistic by using Weighted Means Score (WMS) formula. The research result about student perception showed that lecturers at Islamic Education Management Study Program had already been applied democratic and humanist learning model perfectly in the interactive learning condition. To realize a democratic and humanist learning model, lecturer figure is needed that has the knowledge and ability to develop a model of democratic and humanist learning.

Keywords: Perception; Learning model; Democratic, Humanist;
\end{abstract}

\begin{abstract}
Abstrak
Penelitian ini bertujuan untuk mengkaji dan menganalisis persepsi mahasiswa Prodi Manajemen Pendidikan Islam Fakultas Ilmu Tarbiyah dan Keguruan IAIN Sultan Amai Gorontalo tentang penerapan model pembelajaran yang demokratis dan humanis. Jumlah sampel adalah 98 responden. Teknik analisis data menggunakan statistik deskriptif dengan rumus Weighted Means Score (WMS). Hasil penelitian mengenai persepsi mahasiswa menunjukkan bahwa model pembelajaran demokratis dan humanis sudah diterapkan dengan baik dalam suasana pembelajaran yang interaksi dan interaktif. Untuk mewujudkan model pembelajaran yang demokratis dan humanis, diperlukan sosok dosen yang memiliki pengetahuan dan kemampuan untuk mengembangkan model pembelajaran demokratis dan humanis
\end{abstract}

Kata Kunci: Persepsi; Model Pembelajaran; Demokratis, Humanis; 


\section{Introduction}

A democratic and humanist learning model is an educational model that developed in the educational environment at this time towards the liberation of students with all their existence in developing their own potential to be actively involved in constructing their knowledge and understanding and the ability to think creatively and critically in learning. It is the task and challenge of teachers to give the democratic and humanist learning to their students. The students not only can enjoy the freedom and democratic situation in the learning process, but also can get the democratic learning through the habitations and democratic cultures, which are created in class through the discussion activity, work in-group, question and answer activity and the freedom to express ideas and thoughts and also can appreciate other people's opinion. However, it needs to be anticipated that students may not absolutely set free, they still need to be guided to make sure that the freedom given is not misused, include the lecturing model implemented by lecturers.

College students are one of social groups in scientific society who should have the characteristics of dynamic academic life. The dynamism of college students' life is reflected in their behaviour and critical, creative, innovative and be productive to the college living phenomena and also at the environment in their surroundings. The existence of democratic and humanist learning that is applied by lecturers to students is expected not only to give freedom to students to express their ideas and thoughts, but also need to be aware that everyone's ideas and thoughts are different. A student may express his/her ideas or opinions but outside of his/her idea there are ideas and thoughts of other students that are different from him/her. This awareness needs to be instilled in students that above the freedom given to an individual, there are differences that come from each person. But the reality is contrast to the fact that many students do not understand the democratic and humanist concepts as a whole unit. This can be seen from the existing learning conditions, including resolving differences of opinion with violence or fighting, not respecting or disparaging the 
opinions of others who are different from their opinions, and so on. The problem faced in the implementation of the current lecture, generally the lecturer dominates the class by giving a continual explanation in the classroom, while the students sit quietly but in their hearts are thrilled because they are not given a creative space to express their thoughts and opinions and of course this thing inhibits the ability of students in communicating.1

Another problem is the belief that there is only one way to conduct learning, which is generally through a traditional paradigm based on authoritarianism. This perspective raises many challenges for educators who offer different ways of teaching by using a more democratic modern learning paradigm.2 Furthermore, to trigger a transformation towards humanization and liberation, it is explicitly very important for an educator to have the confidence and ability to support the development of humanist learning to improve the dignity, abilities and achievements of students even though they come from different backgrounds. 3

By observing the problems above, it indicates that the problems associated with the learning model conducted so far have come from lecturers and students. From the lecturers, the problems faced are more psychological. However, the lecturers have been portrayed as the knowing anything person and they are very capable. Furthermore, there is an expression that states a lecturer is a teacher who puts the lecturer in a superior position above the students. Lecturers do have to be authoritative both academically and morally, but that does not mean that they have to be dictatorial and authoritarian. While the problem that comes

1Han, Hayhan. 2014. "Transforming EFL Classes from Lecturing to Cooperative Learning". Journal of Language Teaching and Research, 5, No. 4: 948-952.

2Dragon, Donna A. 2015. "Creating Cultures of Teaching and Learning: Conveying Dance and Somatic Education Pedagogy". Journal of Dance Education, 15, No. 1: 25-32.

3del Carmen Salazar, María. 2013. “A Humanizing Pedagogy: Reinventing the Principles and Practice of Education as a Journey Toward Liberation". Review of Research in Education AERA, 37, No. 1: 121-148. 
from students is the lack of courage to express their ideas and thoughts. During this time they have been conditioned to be passive, accepting any lecturer information without criticism. This condition must be changed by encouraging them to present their ideas and thoughts and appreciate them. Whatever students' opinion, lecturers must be able to give a positive appreciation. Thus, it is important to apply a democratic and humanist learning model in developing students' creative and critical thinking skills in lectures to express opinions, ideas and ideas in accordance with the learning style and characteristics of students, while research related to this problem is still very limited. Therefore, this study aims to examine and analyze the application of a democratic and humanist learning model based on the perceptions of students of Islamic Education Management Study Program, Faculty of Teacher training and education Islamic State Institute (IAIN) Sultan Amai Gorontalo.

\section{Method}

This research is a type of quantitative research with explanatory descriptive approach to describe a symptom, event that occurs systematically, factually and accurately related to the application of a democratic and humanist learning model based on student's perceptions. The subject of this research was the students of Islamic Education Management Study Program, Faculty of Teacher Training and Education Islamic State Institute (IAIN) Sultan Amai Gorontalo at even semester academic year 2017/2018 which consist of 452 students with sampling technique by using simple random sampling, it was obtained 98 students as the sample.

The collecting data technique used observation, questionnaire, and documentation. For data analysis technique used was descriptive statistic with Weighted Means Score (WMS) formula to count the general tendency of respondents to the research variable. This technique used to find the description of respondent's score tendency in every item as the criteria or applicable benchmarks, by these following steps:4

4Sudjana. 2005. Metoda Statistika. Bandung: Tarsito. hlm. 67. 
1. The value is given to each alternative answer selected from the things asked in the questionnaire using a Likert scale whose values are between 1 and 5 .

2. Counting the frequency of every alternative answer chosen by respondents in every question item in questionnaire.

3. Counting the number of answer's value chosen by respondents at every question, it is conducted by counting the frequency of respondents who choose those alternative answers, then they are multiplied by that alternative value.

4. Counting the mean $(x)$ for every question item in questionnaire, by using Weighted Means Score (WMS) formuxa as follow:

$$
X=\frac{1}{N}
$$

Explanation:

$x=$ Mean values

$\mathrm{X}=$ the number of combined scores (frequency times results with weight values for each alternative answer).

$\mathrm{N}=$ the number respondents

5. Matching the average with the frequency table from the WMS calculation as described in the following table.

Table 1. Criteria of Assessment

\begin{tabular}{cccc}
\hline $\begin{array}{c}\text { Value } \\
\text { Range }\end{array}$ & Criterion & Interpretation & Explanation \\
\hline $4,01-5,00$ & Very Good & Always & If $100 \%$ done \\
$3,01-4,00$ & Good & Often & If $70 \%-99 \%$ done \\
$2,01-3,00$ & Enough & Sometimes & If $40 \%-69 \%$ done \\
$1,01-2,00$ & Less & Seldom & If $1 \%-39 \%$ done \\
$0,01-1,00$ & Low & Never & If not done \\
\hline
\end{tabular}

Based on the conversion so it can be concluded how good the implementation of democratic and humanist learning model based on the perception of students of Islamic Education Management Study Program Faculty of Teacher Training and Education, Islamic State Institute (IAIN) Sultan Amai Gorontalo. 


\section{Democratic Learning Model Concept}

Democratic learning basically requires that every learning process in the classroom take place in a balanced manner between the role of educators and students. The position of educators in the classroom facilitates students' learning activities, while students are given various freedoms to perform various activities, innovation, expression, exploration, and selfactualization while still referring to the rules that have been set.5

The implementation of the democratic learning model can be developed as follows: First, it is very normative oriented, namely the implementation of learning must always be based on agreement. Second, learning must be carried out by professionals, because students need learning from those who have competence in their fields, this is important so that teachers are not taken lightly by students. Third, the cultivation of values, culture and habits in class is carried out by all class members themselves through the guidance of the teacher (modeling). Fourth, decision making is not done individually by the teacher. Fifth, all decisions are determined by consensus or compromise and as much as possible avoid the emergence of conflict due to differences of opinion and views. With these five characteristics students indirectly learn to democracy and at the same time foster democratic values within themselves through habituation in learning. Of course the expected democracy is true democracy. This democratic learning brings liberation missions for students.

Furthermore, there are also several humanist principles that can be applied in learning, namely First, the humanun principle, namely the human picture in its nature and position in the world. Second, the principle of humanity is a good and harmonious relationship between a person and another human being which is characterized by subtlety of character and manners, understanding, appreciation, sympathy of togetherness, a sense of mutual responsibility and so on. Third, the principle of humanities, namely the means of education to achieve humanity

5 Murdani. 2015. “Implementasi Pembelajaran Dmokratis: Sebuah Studi Tentang Pembelajaran SKI pada Madrasah Tsanawiyah di Aceh". Jurnal Ilmiah Islam Futura, 14, No. 2: 250-260. 
in the form of cultural knowledge and heritage of various nations. Indicators of the success of humanistic learning, namely when learning to feel happy, passionate, initiative in learning, and there is a change in mindset, behavior and attitude on their own volition. Students are expected to be free, brave, not bound by the opinions of others, and manage their own personal responsibility without reducing the rights of others or violating the rules, norms, discipline and ethics that apply. The point in this humanist learning principle emphasizes a belief that everyone must be respected as a human in the fullest sense.

Regarding the more practical aspects of humanistic learning, it has the following five characteristics: (1) a holistic approach that aims to encourage and develop students with various talents, intelligence and abilities; (2) friendship based on sincerity, caring, kindness, fairness, fairness and reciprocity; (3) a social climate that includes security, trust, acceptance and multiculturalism, together with restraint and tolerance for pluralistic behavior; (4) an intellectual climate that fosters and strengthens the breadth of knowledge and cultural wealth and is autonomous, responsible, critical and creative thinking; (5) teaching methods that provide meaningful learning for students in building their knowledge with the context of life. 6

Observing the various opinions above shows that the democratic and humanist learning model is a learning model that puts forward critical, creative and dialogical thoughts and emphasizes learning activities that provide freedom of creative thinking, critical in expressing opinions, ideas and ideas in accordance with learning styles and characteristics owned by students so as to create democratic and humanist learning conditions.

\section{Result}

Based on the research finding related to the implementation of democratic and humanist learning model based on the perception of students of Islamic Education Management Study

6Aloni, Nimrod, "Empowering Dialogues in Humanistic Education", Educational Philosophy and Theory, 45, No.10:1067-1081. 
Program which is obtained 98 respondents as described as follow:

\section{Description of the democratic and humanist learning's implementation}

The problem reality occured in nowadays learning shows that democratic and humanist learning is urgently enough to be implemented in the class, at least it is based on three reasons, they are: a) the fact that lecturer is not the only one as the larning sources at this technology era. It can not be denied that the access to many information sources such as television, book, newspaper, magazine and internet is very accessible. It makes students already had a package of experiences, knowledges, and information when they are in class. Without democratic attitude in the class, lecturer will become absoulute learning source who can not be disturbed, while students become bridled and then it erases their academic potency; b) the relevant learning principle is to learn how to learn (learning how to learn), it means that the learning at the target class is not only the material mastery, but also the students should learn how to learn (independently). For this things, it can be happened if students are always accustomed to think by themshelves, be brave to express their idea and be brave to do experiments. c) Students as the part of the community members, they should be always accustomed to being democratic, and also free to argue. This can be started in class in the form of learning activities that emphasize the existence of democratic.

Based on the research result analysis which had been conducted related to the implementation of democratic and humanist learning based on the answers from 98 respondents to the 30 question which can be interpreted as follow: 
Table 2. The tendency of mean score of students' perception about the implementation of democratic and humanist learning

\begin{tabular}{clcc}
\hline No & \multicolumn{1}{c}{ Indicator } & $\begin{array}{c}\text { Average } \\
\text { Score }\end{array}$ & Category \\
\hline 1 & Justice & 4.74 & Very Good \\
2 & The Giving of Sanction/warning & 4.59 & Very Good \\
3 & The Development of Learning Activity & 4.47 & Very Good \\
4 & The Giving of Opportunity & 4.38 & Very Good \\
5 & Motivation & 4.40 & Very Good \\
\hline & Average Score & 4.52 & Very Good \\
\hline
\end{tabular}

Based on table 1, it can be seen that the average score obtained for democratic and humanist learning in the Islamic Education Management Study Program is 4.52 in the excellent category in terms of justice, giving sanctions / warnings, developing learning activities, providing opportunities and motivation for students in the process classroom learning. The findings of this study divided into positive findings and negative findings with the following description:

Positive Finding : from the statements of 98 respondents related to the implementation of democratic and humanist learning in the Management Study Program of Islamic Education showed that out of 30 statement items there were 26 statement items that tend to always be done. Namely in lecturer learning always (1) giving equal opportunities to all students to obtain learning rights in class, (2) All students get the same treatment to get lessons in class, (3) give equal attention to all students in the class when explaining the lesson, (4) When students work on assignments in groups sharing the same attention to each group. (5) Does not distinguish between smart and stupid students and between diligent and lazy, (6) Give students the freedom to get learning materials that are in accordance with the material, (7) Submission of learning material in the classroom in accordance with the developmental stages of the students. (8) Give equal opportunities to each student to ask if there is an explanation of material that is poorly understood, (9) Paying attention to individual student differences in the learning process. (10) Giving warnings to students who are less active in taking lessons, (11) Admonishing 
firmly if there are changes in student behavior that are not in accordance with the rules, (12) Developing initial learning activities which allows students to feel not pressured or forced into learning. (13) Developing a classroom atmosphere that gives students the freedom to develop themselves in accordance with their abilities and knowledge, (14) Building an atmosphere of learning that gives students freedom to move and communicate with lecturers and theme, (15) Develop and build cooperative learning activities, where students can communicate their ideas to other students. (16) Develop interaction of learning freely and openly in expressing ideas, ideas and opinions, (17) Asking students to present experiences that relating to the material to be studied, (18) Invite students to be fully involved in the learning process. (19) Provide opportunities for students to participate in learning, (20) Provide opportunities for students to collaborate in learning, (21) Provide opportunities for students to determine the material that needs to be learned, (22) Develop learning media that provide attraction for students to provide comments or statements with the concept or material being studied. (23) Trying to get closer to students by going around to find out the difficulties of students during the task, (24 ) Give opportunity every $\mathrm{m}$ scholars ask and give critical responses without fear. (25) Request students' opinions about the learning material being discussed, (26) Invite students to express their opinions in front of the class.

Furthermore, there are 4 learning activities that tend to be frequent, they are: (1) familiarizing students to think independently, dare to argue, and experiment without intervention from lecturers, (2) Motivating students to question the various learning substances they receive critically, (3) Cultivating an attitude of courage, critical attitude, and tolerant attitude towards different views, (4) Educating students with disciplinary methods that are supportive and non-punitive.

Negative Finding : from the answers of 98 respondents related to the implementation of democratic and humanist learning in the Islamic Education Management Study Program did not exist. Overall, if it was generalized, it can be concluded 
that democratic and humanist learning carried out by the lecturer is very good.

\section{Description of Democratic Learning Model}

The democratic and humanist learning model referred to this study is a learning pattern that is carried out by lecturers with a democratic atmosphere and conditions that emphasize activities that involve students to think creatively, critically expressing opinions, ideas in accordance with learning styles and characteristics possessed by students. Based on the criteria for measuring the democratic and humanist learning model applied in the Islamic Education Management Study Program, the average score of 4.50 is in the very good category. It means that respondents tend to provide interpretations of answers that lecturers always implement the democratic and humanist learning model very well as presented in the following table.

Table 3. The Score Tendency of Democratic and Humanist Learning Model

\begin{tabular}{clcl}
\hline No & \multicolumn{1}{c}{ Indicator } & $\begin{array}{c}\text { Average } \\
\text { Score }\end{array}$ & Category \\
\hline 1 & $\begin{array}{l}\text { Involving students to think } \\
\text { creatively }\end{array}$ & 4.36 & Very Good \\
2 & $\begin{array}{l}\text { Involving students to think } \\
\text { critically }\end{array}$ & 4.53 & Very Good \\
3 & $\begin{array}{l}\text { The freedom of expressing } \\
\text { opinion, idea and thought }\end{array}$ & 4.49 & Very Good \\
4 & Evaluation and Award & 4.63 & Very Good \\
\hline & $\quad$ Average Score & 4.50 & Very Good \\
\hline
\end{tabular}

The findings of the research related to the democratic and humanist learning model implemented in the Islamic Education Management Study Program based on the answers from 98 respondents can be grouped into positive findings and negative findings, with the findings as follows.

Positive Finding : from 98 respondents' answers indicate that in applying democratic and humanist learning models, they are always (1) familiarizing students to discuss learning material with their friends in small groups. (2) if the discussion method is used, the lecturer presents the techniques or steps will be taken by students during discussion activities, (3) If the problem 
solving method is used in learning, the lecturer will present the techniques or problem solving steps that will be taken by students. (4) If the method of group work is used, learning groups and conveying techniques or group work procedures, (5) Guiding learning groups while working on assignments, (6) Facilitating students to collaborate in solving problems and providing solutions when they occur. (7) Facilitating students to present individual or group work, (8) Give a chance $n$ to students to be able to actively interact and also express their opinions freely and openly. (9) familiarizing students to express their opinions freely and openly, (10) Providing solutions to students towards something that becomes a conversation so that it will bring mutual respect to the opinions of others, (11) Give a positive appreciation for whatever opinions expressed by students without cornering them, (12) Lecturers only facilitate learning activities by letting students work according to their respective abilities and ways, (13) Giving awards according to the ability of students without bias, (14) Reflect or assess activities that have been carried out consistently and programmed, (15) Appreciate the efforts or learning outcomes of students both individually and in groups objectively and fairly.

Negative Finding : from 98 respondents' answers regarding the democratic and humanist learning model applied in the Islamic Education Management Study Program did not exist. From the data analysis, it can be seen that the overall indicators and item statements of the variables of democratic and humanist learning models applied by the lecturers are very good in terms of involving students thinking creatively, critically expressing opinions, ideas and ideas. This is because the average lecturer has taught using cooperative learning models with democratic principles. Likewise, in creating an atmosphere of democratic learning, lecturers conduct group division so that students can collaborate to learn together. Lecturers always associate learning material with the realities of life that occur in the community and involve students thinking creatively, critically in expressing opinions, ideas and ideas, with the aim that students can find their own learning experiences. Learning class discussion 
models are also conducted by lecturers, this learning model aims to see the ability of students to express their opinions orally, process ideas and information. In the discussion the lecturer class has a role in directing the course of the discussion so as not to get out of the problems discussed, the lecturer does not let students discuss arbitrarily, but the process of running the discussion is under the control of the lecturer. After the discussion is over the lecturer gives a reflection on the opinions that have been raised and corrects the students' incorrect opinions.

Furthermore, in the implementation of learning, the lecturer tries to develop teaching materials from existing topics, persuasively encouraging and helping students who are still passive in learning by encouraging them to speak and appear in front of the class. Learning by lecturers has given good changes to students. Based on the observations that the author did during the process, there were several changes in the form of: students felt involved in finding and exploring knowledge about a problem, from any source and expressing their opinions. The courage of students to express their opinions to lecturers and friends develops as expected, because they feel their opinions are heard and appreciated. Students have been able to explain systematically according to their understanding to lecturers and classmates about the material that has been studied. The attitude of respect for the opinions of friends and lecturers has begun to appear in students, this can be seen when there are students who explain, then others listen, and pay close attention. In addition, students are able to make their own conclusions on what they learn.

The findings show generally that the model of democratic and humanist learning has been applied well by the lecturers of the Education Management Study Program based on the perceptions of the students being sampled. This is evidenced by the results of classroom observations when the lectures take place showing an attitude of openness and mutual respect among students in discussing or expressing opinions, asking lecturers and answering questions from the lecturer with a family atmosphere, without coercion of the will of the lecturer 
to provide opportunities for each student to explore His knowledge is based on the material being taught and most of the students are active in attending lectures, so this is one of the results obtained in the application of democratic learning models that have been dreamed of by all people and circles in the world of education.

Lecturers in giving lectures are expected to be able to choose and use learning methods in accordance with the material to be delivered, because each student has a very heterogeneous learning style. Ideally, a lecturer must use multi methods, which is varying the use of classroom learning methods such as the lecture method combined with question and answer and assignments or discussion method with assignment and so on. This is intended to bridge the needs of students, and avoid the boringness in learning.

The results obtained are inseparable from the supporting and inhibiting factors of the implementation of democratic and humanist learning, which is one of the factors that support democratic and humanist learning by lecturers in the Islamic Education Management Study Program, one of which is influenced by the educational background of lecturers. The lecturers in Islamic Education Management Study Program of Islamic State Institute (IAIN) Sultan of Amai Gorontalo in average have a Doctoral (S3) education. Of course it is very supportive for the lecturers in designing a democratic and humanist learning model and all lecturers have passed certification which is a demand for him to show his professionalism as a lecturer who has obtained a certificate as an educator. Furthermore, the inhibiting factors, one of which is influenced by the lack of innovation in learning done by senior lecturers and cause a pessimistic attitude in carrying out teaching tasks, resulting in the emergence of boredom in serving as an educator. Researchers saw that there were several lecturers in the Islamic Education Management Study Program who had more than 20 years of work experience experiencing boredom in carrying out their duties as lecturers and not trying to improve the quality of learning in the classroom, so there appeared teaching attitudes to release obligations. Boredom arises because 
the lecturers are very lacking in training and updating their knowledge so it makes the relevant lecturers less innovative in learning.

Thus, it can be said that the main obstacles in democratic and humanist learning are conducted when the lecturers are in direct contact with students. Lecturers can succeed in learning if they have the creativity to develop learning models globally and humanity, and learning can work well in accordance with the objectives in the learning plan if they have the ability to develop models of democratic learning and humans by using various learning, using various methods, and utilizing learning media.

\section{Discussion}

Democratic and humanist learning as an integral part of the system of educational activities are a phenomenon that must be improved and developed by the related side who is concerned and involved. This thing involves the curriculum, methods, teaching media, teaching materials, teaching quality, and evaluation of learning in order to create a good democratic and humanist teaching system. Thus, the nature of democratic and humanist learning is an interaction between lecturers and students that occurs positively in classroom learning with mutual respect, views students as individuals who are resourceful, able to think and actively engage in learning.

The pattern of interaction between lecturers and students in implementing democratic and humanist learning in the classroom really depends on the teaching behavior of lecturers in treating their students humanely. This is in line with Taniredja \& Abduh's findings that the obstacles faced by lecturers in developing democratic attitudes of students is that the environment does not provide a good example, there is a discrepancy between what is said by the lecturer and the environment. The solution that can be done by the lecturer that is applying democratic education to students through classroom learning such as to develop a group freedom attitude on students can be practiced through discussion. For example, when in the classroom, students are given the freedom to choose who the 
group members are when discussing. Freedom of expression can be practiced when the question and answer session is in the discussion. To develop a cooperative attitude among students can be done by forming a discussion group. In this way students will try to collaborate with other students to find solutions to the problems given. To develop a tolerance attitude for students can be done during the discussion and question and answer process during the discussion. Where students cannot impose their opinions if what is conveyed is not in accordance with what is cooled by the student. 7

This finding is also consistent with research conducted by Chayato et.al that democratic learning is able to develop the value of openness, value of equality and value of cooperation based on the principle of mutual respect. Openness values developed include training freedom of speech, expressing opinions. Equity values are developed by training the ability to treat others as human beings who have the same benefits, and appreciate differences. Whereas the value of cooperation is developed to train tolerant attitudes and be able to respect others, it does not consider itself to be the right one, egoism in thinking and behaving must be directed so that it will not be a wild, brutal and anarchic act. These values will be formed in behavioral attitudes when given the opportunity to freely express opinions without pressure and freedom to group and actively participate. The responsible freedom is the most important thing, as well as the ability to cooperate in a team, the attitude of respecting differences with tolerance that respects the opinions of others, does not deteriorate, and does not insult other opinions and the ability to do goodness to others. 8

This finding was also reinforced by Rahmat who stated that peaceful, moderate, and tolerant learning was influenced by factors of lecturer openness, substance of inclusive material, and

7 Taniredja, Tukiran dan Abduh, Muhammad. 2016. “Pengembangan Nilai-Nilai Demokratis Mahasiswa Melalui Pendidikan Kewarganegaraan", Jurnal PKn Progresif, 11 No. 2: 331-347.

${ }_{8}$ Chayati, Nur., Supriyanto, Eko dan Yahya, M. 2015. "Pengelolaan Pembelajaran Sikap Demokratis Di SMP Muhammadiyah 1 Kartasura", Jurnal Pendidikan Ilmu Sosial, 25 No. 2: 20-33. 
dialogical-argumentative lecture methods.9 If viewed from the opinion of Paulo Freire which states that every human being has the same right to say the word correctly, namely the right to name the world with his work and actions. Thus, it is wrong if there are people who try to rob others of their rights in the name of their own rights. This situation requires a dialogue of encounters between fellow human beings, so that this will be a means for a person to obtain its meaning as a human being. Humanist learning is rooted in the relationship between educators and students by "respecting the human side, interpersonal and emphasizing the relationship between the two aspects". 10

This basically shows that the model of democratic and humanist learning is important to be applied in lectures in an atmosphere of interaction and interactive learning such as group collaboration, mutual respect for differences of opinion, learning to argue and respect each student who has a different background. If judging from Islamic education based on humanism will depart from the affirmation of human sovereignty and instead see individuals as subjects who have self-awareness to regulate human freedom and act solely for the good of humanity. However, the freedom given also needs to be balanced with responsibility. The suppression of human subjectivity can have an impact on the dominating and exploitative nature of humanity, which in turn can lead to ecological crises that affect natural balance. In this way, this education is designed not merely to serve the issue of human sovereignty but to formulate values.11

Thus these findings indicate that the democratic and humanist learning model is very effective applied by lecturers in

9 Rahmat, Munawar. 2018. "Model Perkuliahan Pendidikan Agama Islam yang Damai, Moderat dan Toleran”, Nadwa: Jurnal Pendidikan Islam, 12 No. 1: 40-64.

10 Huerta, T. M. 2011. "Humanizing pedagogy: Beliefs and practices on the teaching of Latino children". Bilingual Research Journal, 34, No. 1: 38-57.

11Usman, A. H., Shaharuddin, S. A. and Zainal Abidin, S. 2017. "Humanism in Islamic education: Indonesian references". International Journal of Asia Pacific Studies, 13, No.1: 95-113. 
lectures, because this learning model emphasizes more on the planting of shared attitudes and behaviors in working, helping among others in the structure of regular collaboration in groups, able to develop actualization of various potential students, practical attitudes, values, and skills to respect the opinions of their group friends and other groups of dissenting opinions. Given the behavior of lecturers in interacting in the classroom is a manifestation of the performance of lecturers in the classroom, while students' behavior in learning interactively in the classroom is a reflection of the attitude and motivation of learning that exists in him. As a planner, the lecturer must be able to design learning that is appropriate to the conditions and characteristics of students from different backgrounds, as managers, lecturers must be able to create a conducive learning climate so students can learn to hone their skills in creative and critical thinking, feel free to express opinions, ideas and thoughts.

\section{Conclusion}

Students' perceptions related to the democratic and humanist learning model in the Islamic Education Management Study Program are very good. This is shown from the data analysis of all indicators and statement items from the variables of democratic and humanist learning models applied by the lecturers in the very good category in terms of involving students thinking creatively, critically in expressing opinions, ideas and ideas. Democratic and humanist learning is conducted to develop openness which is by respecting the opinions of others and not considering themselves as the most righteous, seeing positively the attitude of others and accepting differences of opinion.

To realize a democratic and humanist learning model, lecturer figure is needed that has the knowledge and ability to develop a model of democratic and humanist learning as a social cultural way to build a democratic and humanist life, not only in behavior but also in learning activities. 


\section{References}

Al-Fandi, Haryanto, Desain Pembelajaran yang Demokratis dan Humanis. Yogyakarta: Ar-Ruz Media, 2011.

Aloni, Nimrod, "Empowering Dialogues in Humanistic Education", Educational Philosophy and Theory, 45, No.10:1067-1081.

Chayati, Nur., Supriyanto, Eko dan Yahya, M. "Pengelolaan Pembelajaran Sikap Demokratis Di SMP Muhammadiyah 1 Kartasura", Jurnal Pendidikan Ilmu Sosial, 25 No. 2 (2015): 20-33.

Del Carmen Salazar, María. "A Humanizing Pedagogy: Reinventing the Principles and Practice of Education as a Journey Toward Liberation". Review of Research in Education AERA, 37, No. 1 (2013): 121-148.

Dragon, Donna A. 2015. "Creating Cultures of Teaching and Learning: Conveying Dance and Somatic Education Pedagogy". Journal of Dance Education, 15, No. 1: 25-32.

Fitriyah, Nur Laili. "Membangun Pembelajaran Demokratis Berwawasan Multikultural". Jurnal Madrasah, 5, No. 1 (2012): 50-60.

Freire, Paulo, Pendidikan Kaum Tertindas. Yogyakarta: LP3S, 2008.

Han, Hayhan, "Transforming EFL Classes from Lecturing to Cooperative Learning". Journal of Language Teaching and Research, 5, No. 4 (2014): 948-952.

Hermawan, Heris. 2012. Filsafat Pendidikan Islam. Jakarta: Direktorat Jenderal Pendidikan Islam

Huerta, T. M. "Humanizing pedagogy: Beliefs and practices on the teaching of Latino children". Bilingual Research Journal, 34, No. 1 (2011) : 38-57.

Murdani. "Implementasi Pembelajaran Dmokratis: Sebuah Studi Tentang Pembelajaran SKI pada Madrasah Tsanawiyah di Aceh". Jurnal Ilmiah Islam Futura, 14, No. 2 (2015): 250260.

Sudja, I Nengah. "Pembelajaran Demokratis Menuju Profesionalisme Guru". Jurnal Santiaji Pendidikan, 3, Nomor 2 (2013): 213-225.

Sudjana, Metoda Statistika. Bandung: Tarsito. 2005. 
Rahmat, Munawar, "Model Perkuliahan Pendidikan Agama Islam yang Damai, Moderat dan Toleran", Nadwa: Jurnal Pendidikan Islam, 12 No. 1 (2018).: 40-64.

Taniredja, Tukiran dan Abduh, Muhammad. "Pengembangan Nilai-Nilai Demokratis Mahasiswa Melalui Pendidikan Kewarganegaraan”, Jurnal PKn Progresif, 11 No. 2 (2016) : 331-347.

Thabroni, Muhammad, dkk. Belajar dan Pembelajaran. Yogyakarta: Ar-Ruz Media, 2011.

Usman, A. H., Shaharuddin, S. A. and Zainal Abidin, S. "Humanism in Islamic education: Indonesian references". International Journal of Asia Pacific Studies, 13, No.1 (2017): 95-113.

Zuhairini, dkk. Filsafat Pendidikan Islam. Jakarta: Bumi Aksara, 2008. 